\title{
Avena sterilis L. Genotypes as a Potential Source of Resistance to Oat Powdery Mildew
}

Sylwia Okoń, Edyta Paczos-Grzęda, Tomasz Ociepa, Aneta Koroluk, Sylwia Sowa, Krzysztof Kowalczyk, and Maria Chrząstek, Institute of Plant Genetics, Breeding and Biotechnology, University of Life Sciences, Lublin, Poland

\begin{abstract}
Okoń S., Paczos-Grzęda E., Ociepa T., Koroluk A., Sowa S., Kowalczyk K. and Chrząstek M. Avena sterilis L. genotypes as a potential source of resistance to oat powdery mildew. Plant Dis. 100:2145-2151.

The aim of the present study was to identify Avena sterilis genotypes demonstrating a high level of resistance against oat powdery mildew, using host-pathogen tests. The study was conducted on 350 A. sterilis genotypes from different parts of the world. Six single-spore isolates of Blumeria graminis (DC.) f. sp. avenae, which demonstrated different levels of virulence to control lines and cultivars, were used in host-pathogen screening tests. To confirm the resistant response of selected genotypes, 13 other isolates were used. Reactions to the isolates were grouped into three classes: resistant, intermediate, and susceptible. Susceptible

cultivars Sam and Fuchs were used as controls to estimate the degree of infection. The results of the screening test showed that 10 genotypes were classified as resistant. The second test based on 13 other isolates revealed that only four of the 10 genotypes were a valuable source of resistance against powdery mildew. The identified genotypes may be used in oat breeding programs to increase the level of resistance against powdery mildew. First, however, further studies aimed at identifying whether this resistance is conditioned by a single gene or combinations of different genes are required.
\end{abstract}

The genus Avena contains about 27 different species from diploid to hexaploid plants with different genome compositions, including several important crop or pasture weeds, occurring throughout the world. Avena sterilis L., also known as sterile oat, is one of the most important wild relatives of cultivated oat that has a global geographical distribution (Thurston and Phillipson 1976). This species is a major component of herbaceous formations in the oak park and forest vegetation. It is an aggressive weed that massively colonizes road sides, crops, and cultivated field edges (Wahl 1970). Moreover, it can also severely reduce crop yields (Balyan et al. 1991, Dhima et al. 2000).

The development of A. sterilis is highly dependent on temperature and rainfall (Fernandez-Quitanilla et al. 1986). The optimal regions for this species are the Mediterranean countries, such as France, northern Spain, northern Greece, Albania, Serbia, and northern Italy. Central and northern Europe are climatically unsuitable for its growth, as a result of excessive cold stress (Castellanos-Frías et al. 2014).

Due to their adaptation to different environmental conditions, wild and weedy oat species, including $A$. sterilis, are characterized by high genetic diversity (Paczos-Grzęda et al. 2007, 2009). Identification of this diversity is very important for the efficient use of wild species in breeding programs. At present, a number of wild Avena species with different ploidy levels are used as donors of valuable traits (Loskutov 1998).

Hybridization with Avena sterilis L. can be used to increase oat genetic variability (Gupta et al. 1986; Lawrence and Frey 1975). A. sterilis genotypes are a valuable source of different agronomically important traits, such as abundant tillering and leaf growth or good adaptation for grazing, which are very important in breeding oat varieties suited for sheep (Brown and Patterson 1992). Sterile oats were also used as a source of genes conditioning the high yield potential of Avena sativa cultivars and better adaptation to different environmental conditions (Lawrence and Frey 1975). A. sterilis also could serve

Corresponding author: S. Okoń; E-mail: sylwia.okon82@gmail.com

Accepted for publication 16 May 2016.

http://dx.doi.org/10.1094/PDIS-11-15-1365-RE

(C) 2016 The American Phytopathological Society as a donor of genes determining high protein and fat content (Thro and Frey 1985). Genes responsible for resistance to nematodes and herbicides have been found in the A. sterilis genome (Rivoal and Cook 1993). Effective resistance genes for oat crown rust and powdery mildew have also been found in sterile oat (Herrmann and Roderick 1996; Kiehn et al. 1976; Roderick et al. 2000; Sebesta et al. 1993).

Powdery mildew, caused by fungus Blumeria graminis (DC.) f. sp. avenae Em. Marchal, is one of the most harmful fungal diseases of oat. This pathogen has been reported as a serious problem in many parts of the world. Oat powdery mildew is common in northwestern Europe, and South America (Aung et al. 1977; Roderick et al. 2000). Crop losses caused by this disease in western Europe range from 5 to $10 \%$ every year (Clifford 1995; Hsam et al. 1997). It also occurs in eastern Europe, including Poland, Austria, Czech Republic, Germany, and Greece (Roderick et al. 2000; Sebesta et al. 1991). The most effective method of controlling and limiting the consequences of powdery mildew is the introduction of crop cultivars containing effective resistance genes. To date, eight genes conferring resistance to oat powdery mildew have been characterized, but only three, Pml, $P m 3$, and Pm6, were used in breeding programs (Hsam et al. 1997, 1998; Okoń 2012; Sánchez-Martín et al. 2011). Okoń (2015) showed that most of these genes are not effective against the existing powdery mildew populations. The author demonstrated that only two genes, $P m 4$ and $P m 7$, are still effective.

Resistance to powdery mildew is decreasing due to the emergence of new pathotypes; therefore, there is a need to search for novel and effective sources of resistance to powdery mildew in oat. Wild oat species seem to be an enormous reservoir of resistance to this pathogen (Hsam et al. 1997, 1998). Because of this fact, the objective of the present study was to identify Avena sterilis genotypes with high levels of resistance to oat powdery mildew.

\section{Materials and Methods}

The plant materials used in this study were 350 Avena sterilis genotypes from different parts of the world (Fig. 1). Oat accessions were provided by the following gene banks: Genebank IPK Gatersleben (Germany), genotype symbol AVE; Plant Gene Resources of Canada (Saskatoon, Canada), genotype symbol CN; National Germplasm Resources Laboratory (Beltsville, MD, U.S.A.), genotype symbol PI; and the National Center for Plant Genetic Resources (IHAR) (Poland), without symbol. Powdery mildew susceptible cultivars (Fuchs 
and Sam) and lines with known resistance genes (Bruno, Pm6; Jumbo, Pm1; Mostyn, Pm3; AV1860, Pm4; and APR122, Pm7) were used as controls in host-pathogen tests. Control plant materials were supplied by S. L. K. Hsam from the Technical University of Munich, Germany.
Single-spore Blumeria graminis DC. f. sp. avenae isolates were obtained according to the method described by Okoń and Kowalczyk (2012). Pathogen populations were collected from random fields located in different parts of Poland. Single colonies from each collected leaf were transferred to the susceptible cultivar Fuchs. More than 100

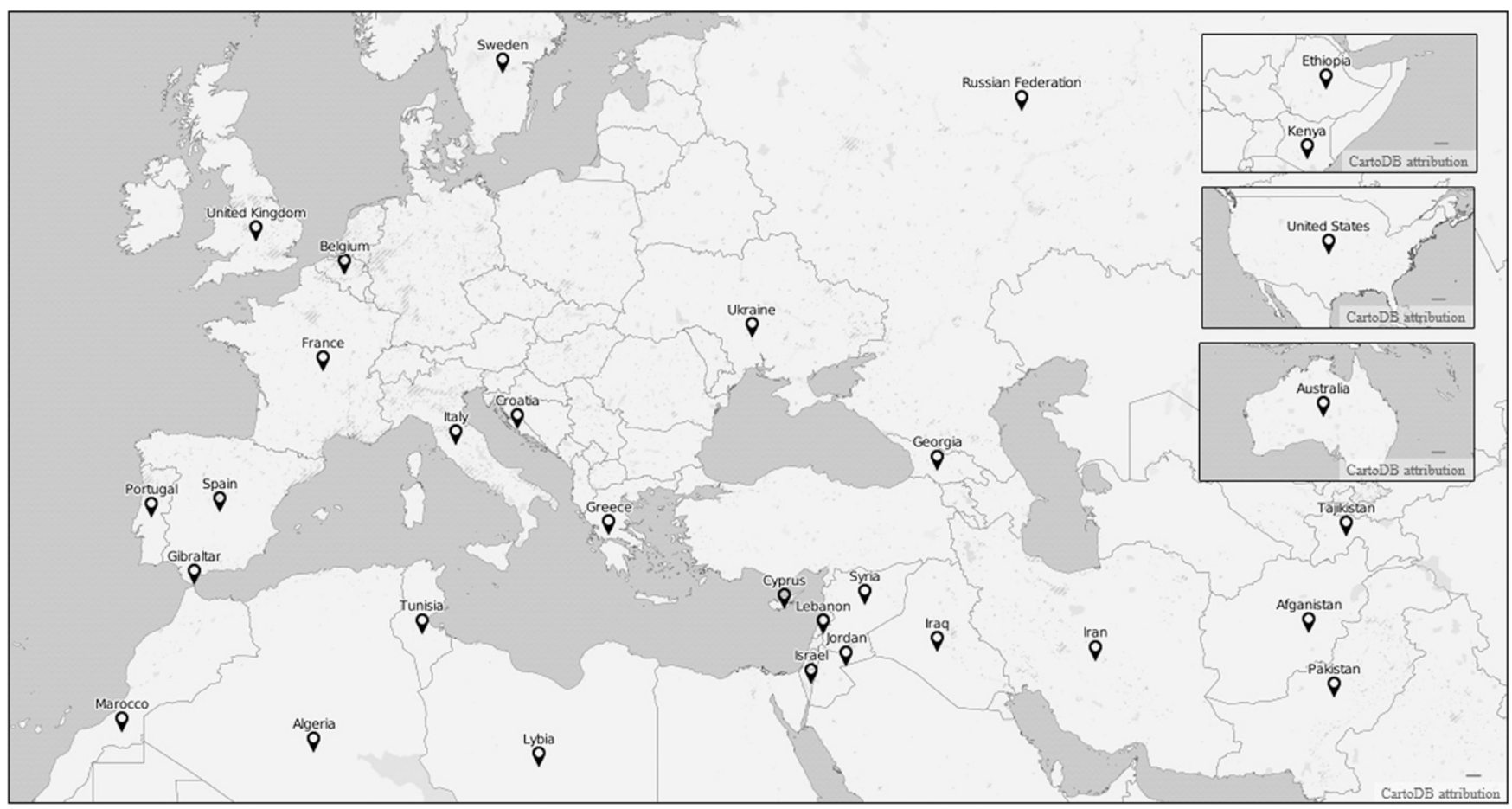

Fig. 1. Distribution of Avena sterilis genotypes used in host-pathogen tests to search for new sources of resistance to powdery mildew in oat.

Table 1. Reaction of control cultivars and lines carrying known resistant genes to powdery mildew after inoculation with Blumeria graminis f. sp. avenae isolates selected for screening tests

\begin{tabular}{|c|c|c|c|c|c|c|c|}
\hline \multirow[b]{2}{*}{ Powdery mildew Isolates } & \multicolumn{7}{|c|}{ Control lines and cultivars ${ }^{a}$} \\
\hline & Bruno Pm6 & Jumbo Pm1 & Mostyn Pm3 & Av1860 Pm4 & APR122 Pm7 & Sam & Fuchs \\
\hline MCh2010/3 & $\mathrm{S}$ & $S$ & $\mathrm{~S}$ & $\mathrm{R}$ & $S$ & $\mathrm{~S}$ & $\mathrm{~S}$ \\
\hline MCh2011/1 & $\mathrm{S}$ & $\mathrm{S}$ & $\mathrm{R}$ & $\mathrm{R}$ & $\mathrm{R}$ & $\mathrm{S}$ & $\mathrm{S}$ \\
\hline MCh2011/4 & I & $\mathrm{R}$ & I & $\mathrm{R}$ & I & $\mathrm{S}$ & $\mathrm{S}$ \\
\hline MCz2013/1 & S & I & S & $\mathrm{R}$ & $\mathrm{R}$ & S & S \\
\hline MSt 2012/1 & $\mathrm{R}$ & S & I & $\mathrm{R}$ & $\mathrm{R}$ & S & S \\
\hline MSt2012/4 & S & S & $\mathrm{S}$ & $\mathrm{R}$ & I & S & S \\
\hline
\end{tabular}

${ }^{\mathrm{a}} \mathrm{R}=$ resistant, $\mathrm{I}=$ intermediate, and $\mathrm{S}=$ susceptible.

Table 2. Reaction of control cultivars and lines carrying known resistant genes to powdery mildew after inoculation with Blumeria graminis f. sp. avenae isolates selected to confirm the results obtained in screening tests

\begin{tabular}{|c|c|c|c|c|c|c|c|}
\hline \multirow[b]{2}{*}{ Powdery mildew Isolates } & \multicolumn{7}{|c|}{ Control lines and cultivars ${ }^{a}$} \\
\hline & Bruno Pm6 & Jumbo Pm1 & Mostyn Pm3 & Av1860 Pm4 & APR122 Pm7 & Sam & Fuchs \\
\hline MBi2014/1 & 4 & 0 & 4 & 0 & 1 & 4 & 4 \\
\hline MCh2010/2 & 3 & 3 & 3 & 0 & 0 & 4 & 4 \\
\hline MCh2014/4 & 4 & 4 & 4 & 0 & 2 & 4 & 4 \\
\hline MCi2014/2 & 4 & 4 & 4 & 0 & 2 & 4 & 4 \\
\hline MCz2013/4 & 4 & 0 & 4 & 0 & 1 & 4 & 4 \\
\hline MCz2014 & 4 & 4 & 4 & 0 & 0 & 4 & 4 \\
\hline $\mathrm{MCu} 2014 / 2$ & 4 & 4 & 4 & 0 & 1 & 4 & 4 \\
\hline MMk2014 & 4 & 4 & 4 & 1 & 1 & 4 & 4 \\
\hline MP12014/1 & 0 & 4 & 4 & 0 & 2 & 4 & 4 \\
\hline MSk2014 & 4 & 4 & 4 & 0 & 0 & 4 & 4 \\
\hline MSt2013/2 & 4 & 4 & 4 & 0 & 0 & 4 & 4 \\
\hline MSt2013/3 & 4 & 4 & 4 & 0 & 0 & 4 & 4 \\
\hline MZb2014/1 & 4 & 3 & 4 & 0 & 2 & 4 & 4 \\
\hline
\end{tabular}

a Scale 0 to 4 , where 0 means lack of powdery mildew symptoms and 4 means powdery mildew mycelium takes up over $50 \%$ of leaf surface. 
single-spore isolates were obtained. Virulence of these isolates was defined on the basis of the host-pathogen tests carried out on a set of control lines and cultivars (data not shown).

For screening tests of $A$. sterilis genotypes, six single-spore isolates with different levels of virulence to the control lines and cultivars were used (Table 1.). In a follow-up test, 13 of the most virulent isolates were used to confirm the resistance of selected resistant genotypes from the first test (Table 2.). Host-pathogen tests were carried out on the first leaves of 10-day-old seedlings, according to the method described by Okoń and Kowalczyk (2012). Two leaf fragments of each of the A. sterilis genotypes were placed on 12-well culture plates amended with benzimidazole agar (6 $\mathrm{g}$ of agar per 1 liter of water and $35 \mathrm{mg}$ of benzimidazole per liter). Control genotypes were put into the first and last well of each dish. The plates with the leaf fragments were inoculated in an inoculation tower by applying about 500 to 700 spores of powdery mildew per square centimeter. The dishes were then incubated in a phytotron at about $17^{\circ} \mathrm{C}$ and light intensity of approximately $4 \mathrm{kLx}$. Inoculated leaves were rated 10 days after inoculation and reactions were grouped into three classes: resistant, in which leaf area with visible pustules ranging from 0 to $20 \%$ relative to Fuchs, intermediate, in which leaf area with visible pustules ranging from 20 to $50 \%$, and susceptible, in which the powdery mildew pustules are visible on more than $50 \%$ of the leaf area (Hsam et al. 1997). To confirm the reliability of the results, every test was repeated twice.

The selected resistant genotypes from the phytotron assay were tested in experimental plots under natural infection to gather additional information on their reaction to powdery mildew. The experimental plots were located in the eastern part of Poland. Grains from all A. sterilis genotypes and the set of control cultivars and lines were densely sown (approximately 200 grains per square meter) in two-row plots, with a row spacing of $20 \mathrm{~cm}$. The same cultivars and lines used in host-pathogen tests, with defined resistance genes against powdery mildew, were used as controls in field experiments. Plant response to the attack of powdery mildew under natural conditions was rated on a 0 to 4 scale, where 0 means lack of powdery mildew symptoms and 4 means powdery mildew pustules occupy over $50 \%$ of the leaf surface. All plots were rated for powdery mildew twice, once when the first symptoms were detected and, again, two weeks later when the disease developed.

\section{Results}

Of the 350 genotypes evaluated, 10 were characterized as being total resistant to the powdery mildew isolates used in the first screening tests. A total of 137 genotypes showed a moderate level of resistance against the selected isolates; among them, 52 genotypes were resistant to a single isolate used in host-pathogen tests.

Genotypes originating from African countries showed a low level of resistance to the powdery mildew isolates tested. Only two genotypes from Tunisia, out of the 108 tested from this region, were resistant to powdery mildew isolates (Fig. 2; Table 3).

Four genotypes from Libya were resistant to one or two isolates, the rest of the genotypes from this region were totally susceptible (Fig. 2; Tables 3 and 4).

Almost all genotypes derived from Middle East countries were susceptible to powdery mildew. Only one genotype from Israel

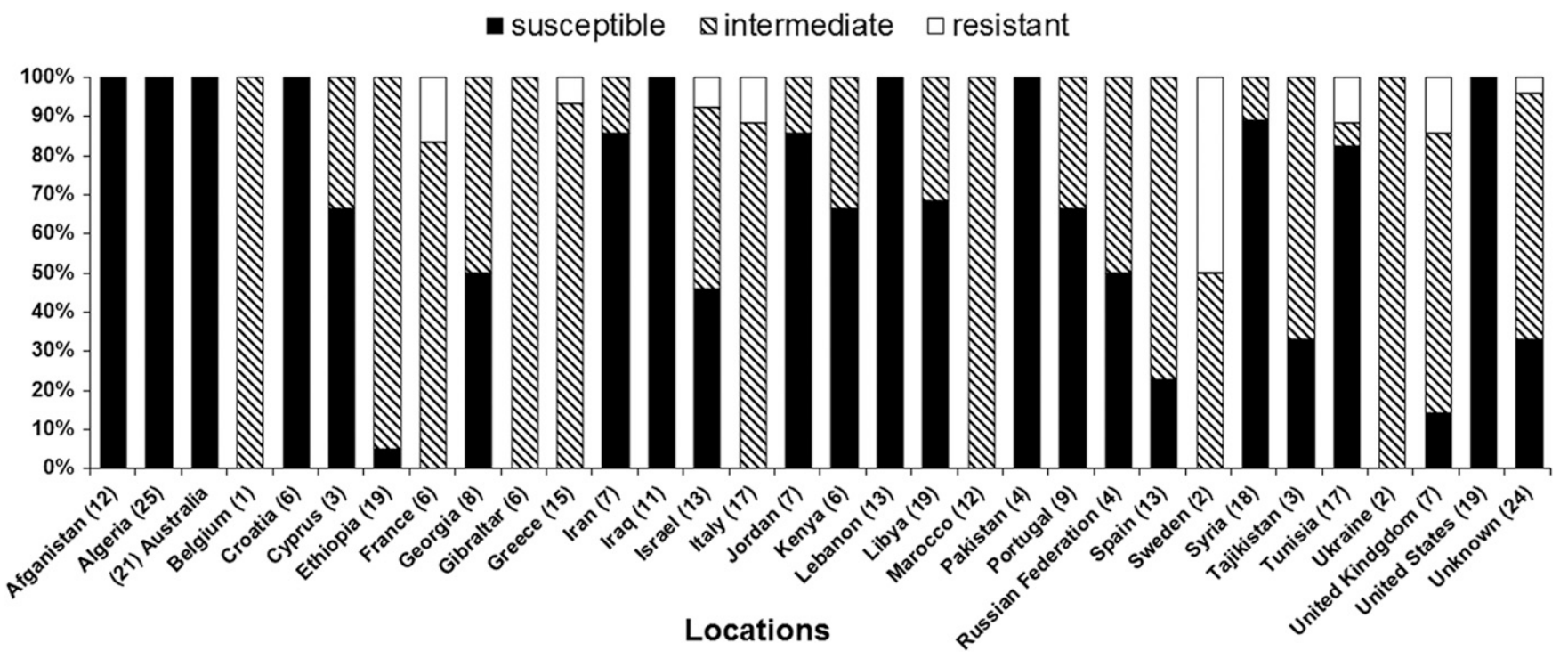

Fig. 2. Reaction of Avena sterilis genotypes from different countries to powdery mildew isolates used in host-pathogen tests.

Table 3. Avena sterilis genotypes resistant to all powdery mildew isolates used in screening tests

\begin{tabular}{|c|c|c|c|c|c|c|c|c|}
\hline \multirow[b]{2}{*}{ Accession number } & \multirow[b]{2}{*}{ Country of origin } & \multirow[b]{2}{*}{ Source $^{\mathbf{a}}$} & \multicolumn{6}{|c|}{ Powdery mildew isolates ${ }^{\mathbf{b}}$} \\
\hline & & & MCh2010/3 & MCh2011/1 & MCh2011/4 & MCz2013/1 & MSt2012/1 & MSt2012/4 \\
\hline CN 67383 & France & GRIN-CA & $\mathrm{R}$ & $\mathrm{R}$ & $\mathrm{R}$ & $\mathrm{R}$ & $\mathrm{R}$ & $\mathrm{R}$ \\
\hline 52280 & Unknown & IHAR & $\mathrm{R}$ & $\mathrm{R}$ & $\mathrm{R}$ & $\mathrm{R}$ & $\mathrm{R}$ & $\mathrm{R}$ \\
\hline CN 66606 & United Kingdom & GRIN-CA & $\mathrm{R}$ & $\mathrm{R}$ & $\mathrm{R}$ & $\mathrm{R}$ & $\mathrm{R}$ & $\mathrm{R}$ \\
\hline CN 22667 & Tunisia & GRIN-CA & $\mathrm{R}$ & $\mathrm{R}$ & $\mathrm{R}$ & $\mathrm{R}$ & $\mathrm{R}$ & $\mathrm{R}$ \\
\hline CN 22668 & Tunisia & GRIN-CA & $\mathrm{R}$ & $\mathrm{R}$ & $\mathrm{R}$ & $\mathrm{R}$ & $\mathrm{R}$ & $\mathrm{R}$ \\
\hline CN 58106 & Sweden & GRIN-CA & $\mathrm{R}$ & $\mathrm{R}$ & $\mathrm{R}$ & $\mathrm{R}$ & $\mathrm{R}$ & $\mathrm{R}$ \\
\hline CN 113554 & Italy & GRIN-CA & $\mathrm{R}$ & $\mathrm{R}$ & $\mathrm{R}$ & $\mathrm{R}$ & $\mathrm{R}$ & $\mathrm{R}$ \\
\hline PI 287211 & Israel & GRIN-NPGS & $\mathrm{R}$ & $\mathrm{R}$ & $\mathrm{R}$ & $\mathrm{R}$ & $\mathrm{R}$ & $\mathrm{R}$ \\
\hline CN 113536 & Italy & GRIN-CA & $\mathrm{R}$ & $\mathrm{R}$ & $\mathrm{R}$ & $\mathrm{R}$ & $\mathrm{R}$ & $\mathrm{R}$ \\
\hline CN 67349 & Greece & GRIN-CA & $\mathrm{R}$ & $\mathrm{R}$ & $\mathrm{R}$ & $\mathrm{R}$ & $\mathrm{R}$ & $\mathrm{R}$ \\
\hline
\end{tabular}

${ }^{\mathrm{a}}$ GRIN-CA = Plant Gene Resources of Canada (Saskatoon, Canada), IHAR = National Center for Plant Genetic Resources (Radzików, Poland), GRIN-NPGS = National Germplasm Resources Laboratory (Beltsville, MD, U.S.A.).

${ }^{\mathrm{b}} \mathrm{R}=$ resistant, $\mathrm{I}=$ intermediate, and $\mathrm{S}=$ susceptible. 
Table 4. Avena sterilis genotypes resistant for one to three powdery mildew isolates

\begin{tabular}{|c|c|c|c|c|c|c|c|c|}
\hline \multirow[b]{2}{*}{ Accession number } & \multirow[b]{2}{*}{ Country of origin } & \multirow[b]{2}{*}{ Source ${ }^{a}$} & \multicolumn{6}{|c|}{ Powdery mildew isolates ${ }^{b}$} \\
\hline & & & MCh2010/3 & MCh2011/1 & MCh2011/4 & MCz2013/1 & MSt2012/1 & MSt2012/4 \\
\hline AVE 2055 & Belgium & IPK & $\mathrm{S}$ & $S$ & $\mathrm{I}$ & I & $\mathrm{S}$ & $\mathrm{R}$ \\
\hline CN 67381 & France & GRIN-CA & I & I & I & I & I & $\mathrm{R}$ \\
\hline CN 21790 & France & GRIN-CA & $\mathrm{R}$ & S & $\mathrm{R}$ & I & I & $\mathrm{R}$ \\
\hline CN 21792 & France & GRIN-CA & I & I & $\mathrm{R}$ & I & $\mathrm{R}$ & I \\
\hline AVE 1510 & France & IPK & I & S & I & I & $\mathrm{R}$ & $\mathrm{R}$ \\
\hline CN 21872 & Gibraltar & GRIN-CA & I & S & I & I & $\mathrm{R}$ & $\mathrm{S}$ \\
\hline CN 67451 & Gibraltar & GRIN-CA & $\mathrm{R}$ & I & I & I & I & I \\
\hline CN 67350 & Greece & GRIN-CA & I & S & $\mathrm{R}$ & I & I & I \\
\hline CN 67345 & Greece & GRIN-CA & $\mathrm{R}$ & I & I & $\mathrm{R}$ & I & I \\
\hline CN 67343 & Greece & GRIN-CA & $\mathrm{R}$ & $S$ & $\mathrm{R}$ & I & I & I \\
\hline CN 67351 & Greece & GRIN-CA & I & S & I & I & I & $\mathrm{R}$ \\
\hline CN 67344 & Greece & GRIN-CA & $\mathrm{R}$ & I & I & I & I & I \\
\hline AVE 245 & Greece & IPK & $\mathrm{S}$ & S & I & I & $\mathrm{S}$ & $\mathrm{R}$ \\
\hline AVE 446 & Greece & IPK & $\mathrm{S}$ & S & I & I & $\mathrm{S}$ & $\mathrm{R}$ \\
\hline AVE5009 & Iran & IPK & I & S & I & I & $S$ & $\mathrm{R}$ \\
\hline CN 113537 & Italy & GRIN-CA & $\mathrm{R}$ & I & $\mathrm{R}$ & I & I & I \\
\hline CN 113539 & Italy & GRIN-CA & I & I & $\mathrm{R}$ & I & $S$ & I \\
\hline CN 113549 & Italy & GRIN-CA & $\mathrm{R}$ & $\mathrm{R}$ & $\mathrm{R}$ & I & $S$ & I \\
\hline CN 113550 & Italy & GRIN-CA & $\mathrm{R}$ & I & I & $\mathrm{S}$ & I & I \\
\hline CN 113552 & Italy & GRIN-CA & I & I & $\mathrm{R}$ & $\mathrm{S}$ & I & I \\
\hline CN 113553 & Italy & GRIN-CA & I & S & $\mathrm{R}$ & I & $\mathrm{R}$ & I \\
\hline AVE 531 & Italy & IPK & I & $S$ & I & I & I & $\mathrm{R}$ \\
\hline CN 45569 & Jordan & GRIN-CA & $\mathrm{S}$ & $S$ & I & $\mathrm{R}$ & I & I \\
\hline CN 21811 & Libya & GRIN-CA & $S$ & $\mathrm{R}$ & $S$ & $S$ & $S$ & $S$ \\
\hline CN 21821 & Libya & GRIN-CA & $\mathrm{S}$ & $S$ & $\mathrm{R}$ & $\mathrm{R}$ & $\mathrm{S}$ & $S$ \\
\hline CN 67409 & Libya & GRIN-CA & $\mathrm{S}$ & $S$ & $S$ & $\mathrm{R}$ & $\mathrm{R}$ & $S$ \\
\hline AVE 2116 & Libya & IPK & I & S & $\mathrm{R}$ & I & I & I \\
\hline AVE 534 & Morocco & IPK & $\mathrm{R}$ & S & I & I & $S$ & $\mathrm{R}$ \\
\hline CN 64606 & Portugal & GRIN-CA & I & I & $\mathrm{R}$ & I & $\mathrm{R}$ & I \\
\hline CN 26489 & Portugal & GRIN-CA & $\mathrm{R}$ & S & I & I & $\mathrm{S}$ & $\mathrm{R}$ \\
\hline AVE 2561 & Portugal & IPK & I & I & I & I & I & $\mathrm{R}$ \\
\hline CN 23006 & Spain & GRIN-CA & I & $S$ & $\mathrm{R}$ & $\mathrm{S}$ & I & I \\
\hline CN 23007 & Spain & GRIN-CA & I & S & $\mathrm{R}$ & $\mathrm{S}$ & I & S \\
\hline CN 23008 & Spain & GRIN-CA & I & S & $\mathrm{R}$ & $\mathrm{S}$ & I & I \\
\hline CN 21873 & Spain & GRIN-CA & I & S & $\mathrm{R}$ & I & I & $S$ \\
\hline AVE 1895 & Spain & IPK & $S$ & S & $\mathrm{R}$ & I & $S$ & $\mathrm{R}$ \\
\hline CN 58107 & Sweden & GRIN-CA & $\mathrm{R}$ & I & I & I & I & $\mathrm{S}$ \\
\hline CN 20301 & Syria & GRIN-CA & $\mathrm{S}$ & S & $\mathrm{R}$ & I & I & $S$ \\
\hline AVE 2532 & Tajikistan & IPK & $\mathrm{S}$ & S & $\mathrm{R}$ & I & $\mathrm{S}$ & $\mathrm{R}$ \\
\hline AVE 2919 & Tunisia & IPK & $\mathrm{S}$ & S & $\mathrm{S}$ & I & $S$ & $\mathrm{R}$ \\
\hline CN 53851 & United Kingdom & GRIN-CA & I & $S$ & $\mathrm{R}$ & I & I & $\mathrm{R}$ \\
\hline CN 58097 & United Kingdom & GRIN-CA & $\mathrm{R}$ & I & $\mathrm{R}$ & I & I & $\mathrm{R}$ \\
\hline CN 65881 & United Kingdom & GRIN-CA & $\mathrm{S}$ & S & $\mathrm{R}$ & I & I & I \\
\hline 51557 & Unknown & IHAR & $\mathrm{R}$ & S & $\mathrm{R}$ & I & $\mathrm{S}$ & I \\
\hline 52337 & Unknown & IHAR & $\mathrm{S}$ & S & $\mathrm{S}$ & I & $\mathrm{S}$ & $\mathrm{R}$ \\
\hline 51834 & Unknown & IHAR & $\mathrm{S}$ & S & $\mathrm{S}$ & I & $S$ & $\mathrm{R}$ \\
\hline 51857 & Unknown & IHAR & $S$ & S & I & I & I & $\mathrm{R}$ \\
\hline 51822 & Unknown & IHAR & $\mathrm{S}$ & S & I & $\mathrm{S}$ & $\mathrm{S}$ & $\mathrm{R}$ \\
\hline 51851 & Unknown & IHAR & $\mathrm{S}$ & $S$ & $\mathrm{~S}$ & $\mathrm{R}$ & $\mathrm{S}$ & $\mathrm{R}$ \\
\hline 51840 & Unknown & IHAR & $\mathrm{R}$ & S & I & I & $\mathrm{S}$ & $\mathrm{R}$ \\
\hline 51555 & Unknown & IHAR & I & S & I & I & $S$ & $\mathrm{R}$ \\
\hline 51557 & Unknown & IHAR & I & S & I & I & $\mathrm{R}$ & $\mathrm{R}$ \\
\hline
\end{tabular}

a IPK = Genebank IPK Gatersleben (Germany), GRIN-CA = Plant Gene Resources of Canada (Saskatoon, Canada), IHAR = National Center for Plant Genetic Resources (Radzików, Poland).

${ }^{\mathrm{b}} \mathrm{R}=$ resistant, $\mathrm{I}$ - intermediate, and $\mathrm{S}=$ susceptible.

Table 5. Reaction of selected Avena sterilis genotypes to 13 powdery mildew isolates used in the second host-pathogen test

\begin{tabular}{|c|c|c|c|c|c|c|c|}
\hline \multirow[b]{2}{*}{ Accession number } & \multirow[b]{2}{*}{ Country of origin } & \multirow[b]{2}{*}{ Source ${ }^{a}$} & \multicolumn{5}{|c|}{ Powdery mildew isolates ${ }^{b}$} \\
\hline & & & MBi2014/1 & MCh2010/2 & MCh2014/4 & MCi2014/2 & MCz2013/4 \\
\hline CN 67383 & France & GRIN-CA & $\mathrm{R}$ & $\mathrm{R}$ & $\mathrm{R}$ & $\mathrm{R}$ & $\mathrm{R}$ \\
\hline 52280 & Unknown & IHAR & $\mathrm{R}$ & $\mathrm{R}$ & $\mathrm{R}$ & I & I \\
\hline CN 66606 & United Kingdom & GRIN-CA & I & $\mathrm{R}$ & I & I & $\mathrm{S}$ \\
\hline CN 22667 & Tunisia & GRIN-CA & $\mathrm{R}$ & $\mathrm{S}$ & $\mathrm{R}$ & I & $\mathrm{S}$ \\
\hline CN 22668 & Tunisia & GRIN-CA & $\mathrm{R}$ & $\mathrm{S}$ & $\mathrm{R}$ & I & $\mathrm{S}$ \\
\hline CN 58106 & Sweden & GRIN-CA & I & $\mathrm{R}$ & I & I & $\mathrm{S}$ \\
\hline CN 113554 & Italy & GRIN-CA & $\mathrm{R}$ & I & $\mathrm{R}$ & I & I \\
\hline PI 287211 & Israel & GRIN-NPGS & $\mathrm{R}$ & I & I & I & I \\
\hline CN 113536 & Italy & GRIN-CA & $\mathrm{R}$ & $\mathrm{R}$ & $\mathrm{R}$ & $\mathrm{R}$ & $\mathrm{R}$ \\
\hline CN 67349 & Greece & GRIN-CA & I & I & I & I & $\mathrm{S}$ \\
\hline
\end{tabular}

(continued on next page)

${ }^{a}$ GRIN-CA = Plant Gene Resources of Canada (Saskatoon, Canada), IHAR = National Center for Plant Genetic Resources(Radzików, Poland), GRIN-NPGS = National Germplasm Resources Laboratory's (Beltsville, MD, U.S.A.).

${ }^{\mathrm{b}} \mathrm{R}=$ resistant, $\mathrm{I}=$ intermediate, and $\mathrm{S}=$ susceptible. 
proved to be resistant to the tested powdery mildew isolates (Fig. 2; Table 3).

Genotypes derived from North America and Australia had very low levels of resistance. Genotypes from Asian countries exhibited moderate levels of resistance or were completely susceptible to the powdery mildew isolates used in the present study (Fig. 2; Table 4).

The highest levels of resistance were demonstrated by genotypes derived from European countries. Among these genotypes, six were identified as resistant to all powdery mildew isolates used in the hostpathogen tests (Fig. 2; Table 3). Fifteen genotypes were resistant to single isolates (Fig. 2; Table 4). Other genotypes were susceptible or exhibited a moderate level of resistance.

Ten A. sterilis genotypes selected as resistant to powdery mildew based on the first screening tests were retested, using 13 additional isolates characterized as being more virulent than those used in the first screening assay (Table 2). These tests were performed to confirm the resistance of the selected genotypes. The test results showed that, among the selected genotypes, only four (CN 67383, CN 113536, CN 22667, and CN 22668) were resistant to powdery mildew. These genotypes showed a resistant response to all isolates used (Table 5). Genotypes CN 67349, CN 113554, and PI 287211 showed resistant or intermediate response to the isolates (Table 5). The remaining genotypes selected in screening tests showed an intermediate or susceptible response to new isolates.

In 2015, genotypes selected as resistant in screening tests were tested in the field under natural infection. Powdery mildew symptoms first appeared on the susceptible cultivars Fuchs and Sam. Among A. sterilis genotypes, CN 66606, PI 287211, 52280, CN22667, and CN 22668 were infected first. Two weeks after the first observation, symptoms of powdery mildew were visible on the genotypes $\mathrm{CN}$ 66606, PI 287211, CN 113554, CN 22667, and CN 22668. Accessions CN 67383, CN 58106, CN 113536, and CN 67349 were highly resistant under natural infection, without visible symptoms of powdery mildew (Table 6). Intensification of symptoms caused by powdery mildew were not observed until the end of the plant growing period.

\section{Discussion}

Wild relatives of cultivated crops are valuable sources of many important traits, including resistance to fungal diseases. Breeding for disease resistance often involves the transfer of resistance factors from related wild species and genera into the cultivated species. Wild relatives of cultivated wheat and barley have been used as donors of many resistance genes for powdery mildew and crown rust (McIntosh et al. 1998; Pickering et al. 1995; Reader and Miller 1991; Shi et al. 1998, Xu and Kasha 1992). Moreover, wild Avena species have also been used as donors of genes for many important traits, such as resistance to pest and fungal diseases (Sánchez-Martín et al. 2012, Sebesta et al. 1993, Tan and Carson 2013). Wild relatives of A. sativa were also used as donors of resistance to powdery mildew. Many sources of resistance to this pathogen have been identified in lower ploidy Avena species (Aung et al. 1977; Herrmann and Roderick 1996; Hoppe and Kummer 1991; Okoń et al.2014; Thomas et al. 1975; Yu and Herrmann 2006). Due to strong sterility barriers that isolate species of lower ploidy levels from the cultivated forms, the transfer of resistant genes cannot be carried out by means of a similar backcrossing program. More effective transfer of resistant genes can be achieved using species that share all genomes with A. sativa. A. sterilis genotypes have been used repeatedly as donors of resistant genes to powdery mildew and crown rust (Hayes and Jones 1966; Wahl 1970), Okoń et al. (2014) tested genotypes belonging to different oat species and demonstrated that, among hexaploid Avena species, A. sterilis seems to be the most promising source of resistance to powdery mildew. The current study screened $350 \mathrm{~A}$. sterilis accessions to identify genotypes with high levels of resistance to powdery mildew. The study showed that some of the tested genotypes could be used as donors of effective resistance. Some of these genotypes were resistant to all powdery mildew isolates used in host-pathogen tests. The present study also showed that the identification of effective and reliable sources of resistance requires multiple assays using a variety of pathogen races. Considering the high variability of the pathogen, it is necessary to screen a wide range of pathogens from different regions. In the present study, the first test showed that 10 genotypes were fully resistant to six selected isolates. However, follow-up tests conducted using a more virulent set of isolates of diverse origin (different years and regions) showed that only four genotypes are, in fact, resistant.

Table 6. Powdery mildew infection of adult plants of Avena sterilis genotypes in field conditions under natural infection

\begin{tabular}{lllcc}
\hline & & & \multicolumn{2}{c}{$\begin{array}{c}\text { Field } \\
\text { observations }\end{array}$} \\
\cline { 4 - 5 } Accession number & Country of origin & Source & First & Second $^{\mathbf{b}}$ \\
\hline CN 67383 & France & GRIN-CA & 0 & 0 \\
52280 & Unknown & IHAR & 1 & 3 \\
CN 66606 & United Kingdom & GRIN-CA & 2 & 4 \\
CN 22667 & Tunisia & GRIN-CA & 1 & 3 \\
CN 22668 & Tunisia & GRIN-CA & 1 & 3 \\
CN 58106 & Sweden & GRIN-CA & 0 & 0 \\
CN 113554 & Italy & GRIN-CA & 0 & 2 \\
PI 287211 & Israel & GRIN-NPGS & 2 & 4 \\
CN 113536 & Italy & GRIN-CA & 0 & 0 \\
CN 67349 & Greece & GRIN-CA & 0 & 0 \\
\hline
\end{tabular}

${ }^{\text {a }}$ GRIN-CA = Plant Gene Resources of Canada (Saskatoon, Canada), IHAR = National Center for Plant Genetic Resources (Radzików, Poland), GRINNPGS = National Germplasm Resources Laboratory (Beltsville, MD, U.S.A.).

b Scale 0 to 4 , where 0 means lack of powdery mildew symptoms and 4 means powdery mildew mycelium takes up over $50 \%$ of leaf surface.

Table 5. (continued from preceding page)

\begin{tabular}{cccccccc}
\hline \multicolumn{7}{c}{ Powdery mildew isolates $^{\mathbf{b}}$} \\
\hline MCz2014 & MCu2014/2 & MMk 2014 & MP12014/1 & MSk2014 & MSt2013/2 & MSt2013/3 & MZb2014/1 \\
\hline I & $\mathrm{R}$ & $\mathrm{R}$ & $\mathrm{R}$ & $\mathrm{R}$ & $\mathrm{R}$ & $\mathrm{R}$ \\
$\mathrm{R}$ & $\mathrm{I}$ & $\mathrm{R}$ & $\mathrm{R}$ & $\mathrm{I}$ & $\mathrm{I}$ & $\mathrm{R}$ \\
$\mathrm{S}$ & $\mathrm{S}$ & $\mathrm{I}$ & $\mathrm{S}$ & $\mathrm{I}$ & $\mathrm{R}$ & $\mathrm{R}$ \\
$\mathrm{R}$ & $\mathrm{R}$ & $\mathrm{R}$ & $\mathrm{S}$ & $\mathrm{R}$ & $\mathrm{R}$ & $\mathrm{R}$ \\
$\mathrm{R}$ & $\mathrm{R}$ & $\mathrm{R}$ & $\mathrm{S}$ & $\mathrm{R}$ & $\mathrm{R}$ & $\mathrm{R}$ \\
$\mathrm{S}$ & $\mathrm{S}$ & $\mathrm{I}$ & $\mathrm{S}$ & $\mathrm{S}$ & $\mathrm{R}$ & $\mathrm{R}$ \\
$\mathrm{I}$ & $\mathrm{I}$ & $\mathrm{R}$ & $\mathrm{I}$ & $\mathrm{I}$ & $\mathrm{I}$ & $\mathrm{S}$ \\
$\mathrm{R}$ & $\mathrm{I}$ & $\mathrm{S}$ & $\mathrm{I}$ & $\mathrm{I}$ & $\mathrm{I}$ \\
$\mathrm{R}$ & $\mathrm{R}$ & $\mathrm{R}$ & $\mathrm{R}$ & $\mathrm{R}$ & $\mathrm{I}$ & $\mathrm{I}$ \\
$\mathrm{R}$ & $\mathrm{I}$ & $\mathrm{I}$ & $\mathrm{I}$ & $\mathrm{I}$ & $\mathrm{R}$ & $\mathrm{I}$ \\
\hline
\end{tabular}


Resistance of adult plants is very important for breeders. Therefore, determination of the adult plant response to stress caused by pathogens plays a crucial role in the selection of disease resistance donors. Resistance in the seedling stage does not always translate into adult plant resistance. In the present study, selected genotypes of $A$. sterilis were tested in the field under natural conditions. The observations revealed that some of the genotypes with a high level of resistance at the seedling stage showed a moderate response as adult plants. Disease symptoms appeared on these plants relatively late in comparison with susceptible checks. Similarly, Tan and Carson (2013), in addition to the host-pathogen test at the seedling stage, estimated the resistance of wild Avena species at the adult plant stage. As in our study, those authors demonstrated that the genotypes resistant at the seedling stage often demonstrated moderate response or were susceptible to the pathogen as adult plants. These authors pointed out that the genotypes resistant at the seedling stage and the adult stage are the most valuable source of resistance. Carson (2009, 2010), who identified A. barbata genotypes with a broadspectrum of resistance to crown rust, came to similar conclusions. The current study showed that the two genotypes selected in hostpathogen tests as being resistant at the seedling stage were also resistant in the field. These results suggest that these two genotypes, $\mathrm{CN}$ 67383 and CN 113536 carry valuable sources of resistance against oat powdery mildew.

A. sterilis genotypes tested in the present study came from different parts of the world and different geographic regions and climatic conditions. The results showed that the genotypes identified as resistant to powdery mildew were acquired from countries located in the Mediterranean region. This observation indicates that the Mediterranean region may be the most suitable to seek for sources of resistance to powdery mildew and, possibly, other biotic and abiotic stresses. In his research, Loskutov (2004) also highlighted the fact that the Mediterranean was the best region to search for the genotypes resistant to fungal diseases, concluding that the resistance most frequently occurred in accessions from North African countries such as Tunisia, Algeria, and Morocco. In addition, A. barbata genotypes identified by Carson $(2009,2010)$ as resistant originated from western Mediterranean countries. Tan and Carson (2013) selected genotypes derived from Morocco to search for new sources of resistance to crown rust. They demonstrated that among the tested genotypes, $67 \%$ were resistant. In the current study, 140 analyzed genotypes came from the Mediterranean countries, of which only six were resistant to the isolates used in host-pathogen tests. Differences in the number of resistant genotypes may result from the fact that the present study tested genotypes belonging only to species A. sterilis. Tan and Carson (2013) tested accessions belonging to different species, and the most resistant genotypes were diploid and tetraploid species. Okoń et al. (2014) also demonstrated that the group of tetraploid species has a higher level of resistance than the group of hexaploid species.

Many studies indicated the need to search for new and effective sources of resistance to fungal disease, due to high variability of pathogens (Hsam et al. 1997, 1998; Okoń 2015; Okoń et al. 2014; Tan and Carson 2013). This work indicates new potential sources of resistance that can be incorporated into oat cultivars to improve the level of resistance to powdery mildew. The results from the current study demonstrated that the most promising sources of resistance among the tested A. sterilis accessions were genotypes CN 67383 and CN 113536 (Plant Gene Resources of Canada, Saskatoon, Canada) from France and Italy.

\section{Acknowledgments}

This work was carried out in the framework of the Programme LEADER V project number: LIDER V/21/p325/L-5/13/NCBR/2014 "Identification of new and effective resistance genes to fungal diseases in oats and development of DNA markers for their identification", supported by the National Research and Development Center.

\section{Literature Cited}

Aung, T., Thomas, H., and Jones, I. T. 1977. The transfer of the gene for mildew resistance from Avena barbata $(4 \mathrm{x})$ into the cultivated oat A. sativa by an induced translocation. Euphytica 26:623-632.
Balyan, R. S., Malik, R. K., Panwar, R. S., and Singh, S. 1991. Competitive ability of winter wheat cultivars with wild oat (Avena ludoviciana). Weed Sci. 39:154-158.

Brown, C. M., and Patterson, F. L. 1992. Conventional oat breeding. Pages 613-656 in: Oat Science and Technology. Marshall, H. G., and Sorrels, M. E., eds. American Society of Agronomy, Madison.

Carson, M. L. 2009. Broad-spectrum resistance to crown rust, Puccinia coronata f. sp. avenae, in accessions of the tetraploid slender oat, Avena barbata. Plant Dis. 93:363-366.

Carson, M. L. 2010. Additional sources of broad-spectrum resistance to Puccinia coronata f. sp. avenae from Canadian accessions of Avena barbata. Plant Dis. 94:1405-1410.

Castellanos-Frías, E., García de León, D., Pujadas-Salva, A., Dorado, J., and Gonzalez-Andujar, J. L. 2014. Potential distribution of Avena sterilis L. in Europe under climate change. Ann. Appl. Biol. 165:53-61.

Clifford, B. C. 1995. Diseases, pest and disorders of oat. Pages 252-278 in: The Oat Crop. R. W. Welch, ed. Chapman \& Hall, London.

Dhima, K. V., Eleftherohorinos, I. G., and Vasilakoglou, I. B. 2000. Interference between Avena sterilis, Phalaris minor and five barley cultivars. Weed Res. 40:549-559.

Fernandez-Quitanilla, C., Navarrete, L., Andujar, J. L. G., Fernandez, A., and Sanchez, M. J. 1986. Seedling recruitment and age-specific survivorship and reproduction in populations of Avena sterilis L. ssp. Ludoviciana (Durieu) Nyman. J. Appl. Ecol. 23:945-955.

Gupta, S. C., Frey, K. J., and Cox, D. J. 1986. Changes in several traits of oats caused by selection for vegetative growth rate. Plant Breed. 97:222-226.

Hayes, J. D., and Jones, I. T. 1966. Variation in the pathogenicity of Erysiphe graminis D.C. f. sp. avenae, and its relation to the development of mildewresistant oat cultivars. Euphytica 15:80-86.

Herrmann, M., and Roderick, H. W. 1996. Characterisation of new oat germplasm for resistance to powdery mildew. Euphytica 89:405-410.

Hoppe, H. D., and Kummer, M. 1991. New productive hexaploid derivatives after introgression of Avena pilosa features. Pages 56-61 in: Cereal Breeding-Eucarpia Cereal Section Meeting, 24-27 Jun 1991, Schwerin, Germany.

Hsam, S. L. K., Paderina, E. V., Gordei, S., and Zeller, F. J. 1998. Genetic studies of powdery mildew resistance in cultivated oat (Avena sativa L.) II. Cultivars and breeding lines grown in northern and eastern Europe. Hereditas 230:227-230.

Hsam, S. L. K., Peters, N., Paderina, E. V., Felsenstein, F., Oppitz, K., and Zeller, F. J. 1997. Genetic studies of powdery mildew resistance in common oat (Avena sativa L.) I. Cultivars and breeding lines grown in western Europe and North America. Euphytica 96:421-427.

Kiehn, F. A., McKenzie, R. I. H., and Harder, D. E. 1976. Inheritance of resistance to Puccinia coronata avenae and its association with seed characteristics in four accessions of Avena sterilis. Can. J. Genet. Cytol. 18:717-726.

Lawrence, P. K., and Frey, K. J. 1975. Backcross variability for grain yield in oat species crosses (Avena sativa L. x A. sterilis L.). Euphytica 24:77-85.

Loskutov, I. G. 1998. The collection of wild oat species of C.I.S. as a source of diversity in agricultural traits. Genet. Resource Crop Evol. 45:291-295.

Loskutov, I. G. 2004. Using of wild species genetic diversity in plant breeding. In: 4th Int. Crop Sci. Congr., Brisbane, Australia.

McIntosh, R. A., Hart, G. E., Devos, K. M., Gale, M. D., and Rogers, W. J. 1998 Catalogue of gene symbols for wheat. Pages 1-235 in: Proc. 9th Intl. Whea Genetics Symp, A. E. Slinkard, ed. University Extension Press, University of Saskatchewan, Saskatoon, Canada.

Okoń, S. M. 2012. Identification of powdery mildew resistance genes in Polish common oat (Avena sativa L.) cultivars using host-pathogen tests. Acta Agrobot. 65:63-68.

Okoń, S., and Kowalczyk, K. 2012. Deriving isolates of powdery mildew (Blumeria graminis DC. f. sp. avenae Em. Marchal.) in common oat (Avena sativa L.) and using them to identify selected resistance genes. Acta Agrobot. 65:155-160.

Okoń, S. M. 2015. Effectiveness of resistance genes to powdery mildew in oat. Crop Prot. 74:48-50.

Okoń, S. M., Chrząstek, M., Kowalczyk, K., and Koroluk, A. 2014. Identification of new sources of resistance to powdery mildew in oat. Eur. J. Plant Pathol. 139: $9-12$

Paczos-Grzęda, E., Chrząstek, M., Okoń, S., Grądzielewska, A., and Miazga, D. 2009. Zastosowanie markerów ISSR do analizy wewnątrzgatunkowego podobieństwa genetycznego Avena sterilis L. Biul. Inst. Hod. i Aklim. Roslin 252:215-223.

Paczos-Grzęda, E., Chrząstek, M., Wacko, S., and Miazga, D. 2007. Ocena podobieństwa genetycznego wybranych form Avena sterilis L. pochodzących z Izraela, Syrii i Libanu. Zesz. Probl. Postepow Nauk Rol. 517:559-567.

Pickering, R. A., Hill, A. M., Michel, M., and Timmerman-Vaughan, G. M. 1995. The transfer of a powdery mildew resistance gene from Hordeum bulbosum L. to barley (H. vulgare L.) chromosome 2 (21). Theor. Appl. Genet. 91:1288-1292.

Reader, S. M., and Miller, T. E. 1991. The introduction into bread wheat of a major gene for resistance to powdery mildew from wild emmer wheat. Euphytica 53: $57-60$

Rivoal, R., and Cook, R. 1993. Plant parasitic nematodes in temperate agriculture. Pages 259-303 in: Nematode pests of cereal. K. Evans, D. L. Trudgill, and J. M. Webster, eds. CAB International, Wallingford, U.K.

Roderick, H. W., Jones, E. R. L., and Sebesta, J. 2000. Resistance to oat powdery mildew in Britain and Europe: A review. Euphytica 136:85-91.

Sánchez-Martín, J., Rubiales, D., and Prats, E. 2011. Resistance to powdery mildew (Blumeria graminis f. sp. avenae) in oat seedlings and adult plants. Plant Pathol. 60:846-856. 
Sánchez-Martín, J., Rubiales, D., Sillero, J. C., and Prats, E. 2012. Identification and characterization of sources of resistance in Avena sativa, A. byzantina and A. strigosa germplasm against a pathotype of Puccinia coronata $\mathrm{f}$. sp. avenae with virulence against the $P c 94$ resistance gene. Plant Pathol. 61: 315-322.

Sebesta, J., Kummer, M., Roderick, H. W., Hoppe, H. D., Cervenka, J., Swierczewski, A., and Müller, K. 1991. Breeding oats for resistance to rusts and powdery mildew in central Europe. Ochr. Rostl. 27:229-238.

Sebesta, J., Roderick, H. W., Chong, J., and Harder, D. E. 1993. The oat line Pc54 as a source of resistance to crown rust, stem rust and powdery mildew in Europe. Euphytica 71:91-97.

Shi, A. N., Leath, S., and Murphy, J. P. 1998. A major gene for powdery mildew resistance transferred to common wheat from wild einkorn wheat. Phytopathology 88:144-147.

Tan, M. Y. A., and Carson, M. L. 2013. Screening wild oat accessions from Morocco for resistance to Puccinia coronata. Plant Dis. 97:1544-1548.
Thomas, H., Leggett, J. M., and Jones, I. T. 1975. The addition of a pair of chromosomes of the wild oat Avena barbata $(2 \mathrm{n}=28)$ to the cultivated oat A. sativa $\mathrm{L} .(2 \mathrm{n}=42)$. Euphytica $24: 717-724$.

Thro, A. M., and Frey, K. J. 1985. Inheritance of groat-oil content and high-oil selection in oats (Avena sativa L.). Euphytica 34:251-263.

Thurston, J. M., and Phillipson, A. 1976. Distribution. Pages 19-64 in: Wild Oats in World Agriculture, an Interpretive Review of World Literature. D. P. Jones, ed. Agricultural Research Council, London.

Wahl, I. 1970. Prevalence and geographic distribution of resistance to crown rust in Avena sterilis. Phytopathology 60:746-749.

Xu, J., and Kasha, K. J. 1992. Transfer of a dominant gene for powdery mildew resistance and DNA from Hordeum bulbosum into cultivated barley (H. vulgate). Theor. Appl. Genet. 84:771-777.

$\mathrm{Yu}$, J., and Herrmann, M. 2006. Inheritance and mapping of a powdery mildew resistance gene introgressed from Avena macrostachya in cultivated oat Theor. Appl. Genet. 113:429-437. 